\title{
Formulations of Milk Cappuccino from Soy Milk with Evaluation Sensories and Benefit of Health
}

\author{
Shafira Nindita, Zayyini Nahdlah \\ Sekolah Tinggi Pariwisata Trisakti \\ Jakarta, Indonesia \\ Shafira.nindita27@gmail.com
}

\begin{abstract}
Cappuccino is beverage from Italy, made from espresso, heated milk, and whipped milk until frothy, but now people are beginning to use soy milk as an alternative milk in making cappuccino. Soy milk is product made from soy bean seed extract, but soy milk has beany flavour and has fat content lower than cow's milk. This study aims to determine technique to make cappuccino from soy milk, sensory evaluation, level of panelist preferences and nutrient content on cappuccino which used soy milk. The technique of making the cappuccino used soy milk were adding non dairy creamer as much as $0 \%, 5 \%$ and $10 \%$, followed by agitation using homogenization techniques for 0 second, 30 seconds, and 60 seconds. The result showed that cappuccino used soy milk with adding of $5 \%$ non dairy creamer and agitating for 30 second can produced cappuccino which is similar cappuccino using cow's milk and most preferred. Sensory evaluation showed cappuccino used soy milk with adding $5 \%$ non dairy creamer and agitating for 30 second produced the highest quantity of froth, flavor, and taste, while cappuccino used soy milk with adding $0 \%$ non dairy creamer and agitating for $\mathbf{3 0}$ second produced the highest color and softness of froth.
\end{abstract}

Keywords- cappuccino, soy milk, non dairy creamer, homogenization

\section{INTRODUCTION}

Cappuccino is beverage from Italy, made from espresso, heated milk, and whipped milk until frothy. Another definition from cappuccino is espresso and microfoam (Anonim, 2015). In this time, it has many other alternatives as a subtitutes for cow's milk in the making cappuccino, one of them is use soy milk. Soy milk is product like cow's milk, but this product made from soy been seed extract. Soy milk is obtained by grinding soy beans that have been soaked in water (Koswara, 2009). The advantage of soy milk is the price is cheap, easy to get, protein content is higher than cow's milk and fat content is lower than cow's milk, so soy milk can be used as alternative to people who are dieting, toddlers and children (Cahyadi, 2004). Another advantage from soy milk is doesn't contain lactose, so this milk can suitable consumed for people who has lactose intolerance. Is someone who doesn't have the lactase enzym in their body, people without lactase enzym in their body can't digest protein from animal (Cahyadi,2004). However, because the fat content in soy milk lower than cow's milk, it's necessary to adding vegetable fat from the outside in order to make foam on cappuccino which is similar to cow's milk. Non dairy creamer is milk or cream substitute that is product of lipid emulsion in water, made from vegetable oils are hydrogenated with the addition of food additives permitted (Anonim, 2012). From the function, non dairy creamer has many advantages than non dairy creamer, among others non dairy creamer using vegetable oils as a source of the fat, that is safe for people with lactose intolerance. Economically, the raw material from non dairy creamer is hydrogenated coconut oil relatively cheaper than milk, so the price of the product in the end also relatively cheap and affordable. Non dairy creamer can be either a powder or liquid and it also can be used in food and beverage to add flavour (Santos, 2008). Beside the addition of fat from the outside in the making of cappuccino, it necessary to agitating the cappuccino that has been added non dairy creamer in order to produce a foam similar to cow's milk by homogenization technique.

Homogenization process is a process to unify the size of fat globules from milk. In milk that has not been process by homogenization technique, the magnitude of fat globules is not uniform, it between 2-10 micrometers. The equipment for uniform of fat globules are called homogenizer (Saleh, 2011). This study aims to determine technique to make cappuccino from soy milk, sensory evaluation, level of panelist preferences and nutrient content on cappuccino which used soy milk.

\section{METHOD}

\section{Equipment and material for research}

The materials used in this research are soybeen seed, $\mathrm{NaHCO}_{3}$, robusta coffe bean, nondairy creamer. The equipment used to make cappuccino with soy milk are bucket, strainer, cotton cloth, measuring cup, scale by camry brand, food processor by health power mixer brand, coffee grinder, coffee machine by saeco brand, equipment for homogenization process by philip brand.

\section{Soybean milk process}

Method of making this soy milk refers to wulandari's method (2003) and modified by the hadiwiyoto's method (1999) to omit the beany flavour from soybean milk. The first phase of making soy milk is washing 200 gr the whole of soy bean seed and separated the soy bean seed form dirty and broken. Next phase is whole soy bean soaked in water with 
$0.25 \%$ baking soda amount of the soy beans for 12 hours. After that wash the soybean with warm water three times and separated the husk. After the soy bean clean, boiling for 30 minute to soften the seed and weaken the enzyme lipokginase. The duration of boling 30 minute start after the water boiling. Next phase is the process of grinding the soy bean that have been soften in the ratio soy: water $=100 \%: 300 \%$. Then filtered the filtrate to get soy milk. Boil that soy milk for 5 minutes.

\section{Cappuccino with soy milk process}

The next process is making cappuccino using soy milk. Soy milk has been processed, then it used as main ingredient in cappuccino process. In this research, using $30 \mathrm{ml}$ espresso as basic ingredient in cappuccino process.

Next process is adding non dairy creamer to $100 \mathrm{ml}$ soy milk, the purpose of adding non dairy creamer from outside is to produce froth, flavour, colour and texture similar to cappuccino using cow's milk. Adding non dairy creamer as much as $0 \%, 5 \%$, and $10 \%$ of the large number of using soy milk. As an example ratio of soy milk and non dairy creamer, soy milk: nondairy creamer 100ml: 5gr. After non dairy creamer added to soy milk, agitating using homogenizer, it purpose to uniform fat globules in soy milk with non dairy creamer mixture and it will produce a number of froth, quantity and height of froth similar to cow's milk. Duration of agitating are 0 second, 30 seconds and 60 seconds. Next process is soy milk that has been mixed with non dairy creamer poured on to espresso, they allow the mixture to stand for 0-10 minutes to test the durability and height of froth. Most people who consume cappuccino started drink cappuccino 5 minutes after cappuccino served and froth from cappuccino using cow's milk can stand for 5 minutes and height of froth from cappuccino using cow's milk of the top milk has been poured. Table 1 following the experimental design cappuccino using soy milk.

\section{Hedonic and descriptive test}

Next step are hedonic and descriptive test with untrained panelist and using scoring method. Descriptive test on cappuccino using soy milk are cover colour, softness of froth, quantity of froth, flavour and taste.

TABLE I. EXPERIMENTAL DESIGN CAPUCCINO USING SOY MILK

\begin{tabular}{llllll}
\hline \multicolumn{1}{c}{ Sample } & Espresso & Soy milk & $\begin{array}{c}\text { Non dairy } \\
\text { creamer (\%) }\end{array}$ & \multicolumn{1}{c}{$\begin{array}{c}\text { Duration of agitation with } \\
\text { homogenizer (second) }\end{array}$} \\
\hline 1 & $30 \mathrm{ml}$ & $100 \mathrm{ml}$ & 0 & 0 \\
2 & $30 \mathrm{ml}$ & $100 \mathrm{ml}$ & 0 & 30 \\
3 & $30 \mathrm{ml}$ & $100 \mathrm{ml}$ & 0 & 60 \\
4 & $30 \mathrm{ml}$ & $100 \mathrm{ml}$ & 5 & 0 \\
5 & $30 \mathrm{ml}$ & $100 \mathrm{ml}$ & 5 & 30 \\
6 & $30 \mathrm{ml}$ & $100 \mathrm{ml}$ & 5 & 60 \\
7 & $30 \mathrm{ml}$ & $100 \mathrm{ml}$ & 10 & 0 \\
8 & $30 \mathrm{ml}$ & $100 \mathrm{ml}$ & 10 & 30 \\
9 & $30 \mathrm{ml}$ & $100 \mathrm{ml}$ & 10 & 60 \\
\hline
\end{tabular}

Hedonic test on cappuccino using soy milk are cover very dislike, dislike, like, very like. Next the data were analyzed using ANOVA and continued with the different test LSD and DMRT with $\alpha=0,05$ to determine the real differences between the samples. Processing data using spss 20.

\section{Nutrient test}

Nutrient test in this research is testing protein level in cappuccino using soy milk with Lowry's method and testing fat level with Mojoinner's method. Both of test are tested in Laboratorium CV.Chemmix Pratama, Bantul, Jogjakarta.

\section{RESULT}

\section{Technique of the making}

In this research, the technique of making cappuccino using soy milk by adding non dairy creamer as much as $0 \%, 5 \%$ and $10 \%$ of the large number of using soy milk, and agitating with homogenization tehcniques. The addition of non dairy creamer on making cappuccino meant to diguise the beany flavour and add flavour to cappuccino using soy milk. The addition of using non dairy creamer is also intended to produce colour, softness and quantity of froth similar to cappuccino using cow's milk. Agitating with homogenization technique are purpose to uniform the fat globules in soy milk that had been given the addition of non dairy creamer, so the the protein in soy milk that has been added non dairy creamer can be emulsified and can produce a softness and durability of froth. Agitating with homogenization tehcnique are also purpose to test the speed of the missing froth durability and height of froth, the test is by standing the cappuccino for 0-10 minutes to see which froth of cappuccino can stand up to 10 minutes and see height of froth similar to cappuccino using cow's milk.

From the test, the result is cappuccino using soy milk with addition of $5 \%$ non dairy creamer can produce colour, softness, quantity and height of froth similar to cappuccino using cow's milk and can stand for 10 minutes. Table 2 following the result endurance of froth. 
TABLE II. RESULTS ENDURANCE OF FROTH

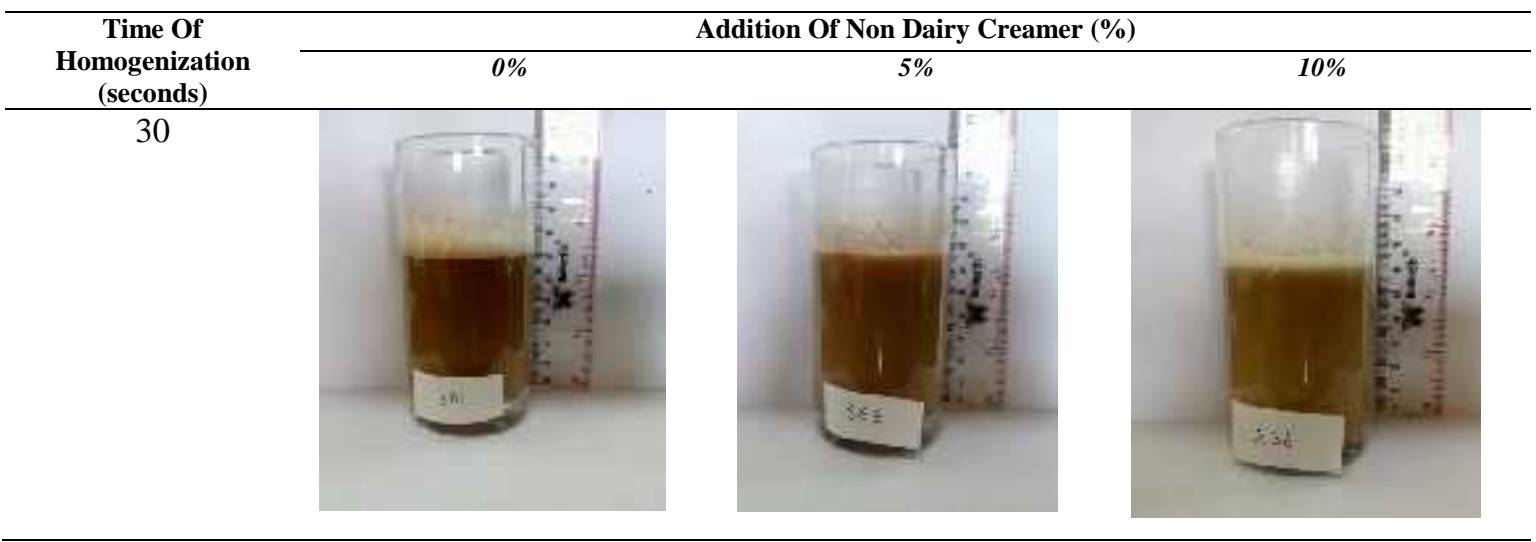

\section{Hedonic test of cappuccino using soy milk}

Hedonic test in this research are cover preference of the colour, softness and quantity of froth, flavour, taste and overall acceptance are shown in Table 3.

TABLE III. HEDONIC TEST LEVEL OF CAPUCCINO

\begin{tabular}{|c|c|c|c|c|c|c|}
\hline \multirow[t]{2}{*}{ Product } & \multicolumn{6}{|c|}{ Mean of hedonic test } \\
\hline & Colour & Softness of froth & $\begin{array}{c}\text { Quantity of } \\
\text { froth }\end{array}$ & Flavour & Taste & $\begin{array}{c}\text { Overall } \\
\text { acceptance }\end{array}$ \\
\hline Cappuccino using cow's milk & $3,30^{\mathrm{a}}$ & $3,30^{\mathrm{a}}$ & $3,20^{\mathrm{b}}$ & $3,20^{\mathrm{a}}$ & $2,70^{\mathrm{b}}$ & $3,00^{\mathrm{ab}}$ \\
\hline Cappuccino using soy milk & $3,20^{\mathrm{a}}$ & $3,10^{\mathrm{a}}$ & $2,30^{\mathrm{a}}$ & $2,70^{\mathrm{a}}$ & $1,70^{\mathrm{a}}$ & $2,50^{\mathrm{a}}$ \\
\hline $\begin{array}{l}\text { Cappuccino soy milk with } 5 \% \\
\text { non dairy creamer }\end{array}$ & $2,90^{\mathrm{a}}$ & $2,70^{\mathrm{a}}$ & $2,70^{\mathrm{ab}}$ & $3,30^{\mathrm{a}}$ & $3,00^{\mathrm{b}}$ & $3,20^{\mathrm{b}}$ \\
\hline $\begin{array}{l}\text { Cappuccino soy milk with } 10 \% \\
\text { non dairy creamer }\end{array}$ & $2,60^{\mathrm{a}}$ & $2,60^{\mathrm{a}}$ & $2,50^{\mathrm{a}}$ & $2,80^{\mathrm{a}}$ & $2,70^{\mathrm{b}}$ & $2,90^{\mathrm{ab}}$ \\
\hline
\end{tabular}

Information:

- Mean from 10 panelis with $\alpha=5 \%$

- The same code in the same column showed no difference

- Scale of value, $1=$ very dislike, $2=$ dislike, $3=$ like, $4=$ very like

From table 3 it can be seen that the highest score of the colour of cappuccino is cappuccino using cow's milk with a score 3,30 which is like, while the lowest score was the cappuccino soy milk with $10 \%$ non dairy creamer with a score 2,60 which dislike, it because the fat content in cow's milk greater than the soy milk is 3,3\% while the soy milk is only $2,0 \%$ per 100 gr material (Astawan, 2004). The highest score of the softness of froth is cappuccino using cow's milk with a score 3,30, which is like and the lowest score was the cappuccino soy milk with $10 \%$ non dairy creamer with a score 2,60 which is dislike, same as colour of cappuccino, it because the fat content in cow's milk greater than the soy milk. The highest score of the quantity of froth is cappuccino using cow's milk is 3,20, which is like, while the lowest score was cappuccino soy milk with $0 \%$ non dairy creamer with a score 2,30 which is dislike. The highest score of the flavour of cappuccino is cappuccino soy milk with $5 \%$ non dairy creamer with a score 3,30 which is like, while the lowest score was the cappuccino soy milk with $0 \%$ non dairy creamer with a score
2,70 which is dislike, it because beany flavour from soy milk. Beany flavour is one of the problems in the processing of soy bean. Beany flavour produced enzym lipokginase on soy beans because that enzyme can decompose fat from soy beans and it can produce the beany flavour (Koswara, 1992). The highest score of the taste of cappuccino is cappuccino soy milk with $5 \%$ non dairy creamer with a score 3,00 , which is like, while the lowest score was the cappuccino soy milk with $0 \%$ non dairy creamer with a score 1,70 which is very dislike, it because the beany flavour on soy milk so less favoured of panelist. The highest score of overall acceptance is cappuccino soy milk with $5 \%$ non dairy creamer with a score 3,20 , which is like, while the lowest score was cappuccino soy milk with $0 \%$ non dairy creamer.

\section{Sensory evaluation cappuccino using soy milk}

Descriptive test in this test are cover colour, softness of froth, quantity of froth, flavour and taste that can be seen in Table 4. 
TABLE IV. SENSORY EVALUATION ON CAPUCCINO

\begin{tabular}{|c|c|c|c|c|c|}
\hline \multirow[t]{2}{*}{ Product } & \multicolumn{5}{|c|}{ Mean of descriptive test } \\
\hline & Colour & Softness of froth & $\begin{array}{c}\text { Quantity of } \\
\text { froth }\end{array}$ & Flavour & Taste \\
\hline Cappuccino using cow's milk & $1,30^{\mathrm{a}}$ & $2,00^{\mathrm{a}}$ & $1,90^{\mathrm{a}}$ & $3,00^{\mathrm{a}}$ & $3,10^{\mathrm{a}}$ \\
\hline Cappuccino using soy milk & $2,40^{\mathrm{b}}$ & $2,30^{\mathrm{a}}$ & $2,80^{\mathrm{b}}$ & $2,40^{\mathrm{ab}}$ & $2,10^{\mathrm{a}}$ \\
\hline Cappuccino soy milk with $5 \%$ non dairy creamer & $1,80^{\mathrm{ab}}$ & $2,10^{\mathrm{a}}$ & $2,90^{\mathrm{b}}$ & $2,40^{\mathrm{ab}}$ & $2,20^{\mathrm{a}}$ \\
\hline Cappuccino soy milk with $10 \%$ non dairy creamer & $1,50^{\mathrm{ab}}$ & $2,50^{\mathrm{a}}$ & $2,80^{\mathrm{b}}$ & $1,80^{\mathrm{a}}$ & $2,10^{\mathrm{a}}$ \\
\hline
\end{tabular}

\section{Remark:}

- Mean from 10 panelist with $\alpha=5 \%$

- The same code in the same column showed no difference

- Scale of value:

Colour

: 1=light brown, 2=brown, 3=dark brown, 4= very dark brown

Softness of froth

: 1=very soft, $2=$ soft, $3=$ not soft, $4=$ very not soft

Quantity of froth

: 1=very much, $2=$ much, $3=$ some, $4=$ few

Flavour

: $1=$ very beany flavour, $2=$ beany flavour, $3=$ not beany flavour, $4=$ not very beanny flavour

Taste

$$
\text { : } 1=\text { very beany taste, } 2=\text { beany taste, } 3=\text { not beany taste, } 4=\text { not very beany taste }
$$

From Table 4 it can be seen that the highest score of the colour of cappuccino is cappuccino soy milk with $0 \%$ non dairy creamer with a score 2,40 is brown, while the lowest score is cappuccino using cow's milk with a score 1,30 is light brown. The highest score of the softness of cappuccino is cappuccino soy milk with $0 \%$ non dairy creamer with a score 2,30 is soft, while the lowest score is cappuccino using cow's milk with a score 2,00 is soft. The highest score of the quantity of cappuccino is cappuccino soy milk with $5 \%$ non dairy creamer with a score 2,90 is lot, while the lowest score is cappuccino soy milk with $0 \%$ non dairy creamer with a score 1,90 is much. The highest score of the flavour of cappuccino is cappuccino using cow's milk with a score 3,00 is not beany flavour, while the lowest score is cappuccino soy milk with $10 \%$ non dairy creamer with a score 1,80 is very beany flavour. The highest score of the taste of cappuccino is cappuccino using cow's milk with a score 3,10 is not beany taste, while the lowest score is cappuccino soy milk with $0 \%$ and $10 \%$ non dairy creamer with a score 2,10 is beany taste.

\section{Fat and protein in cappuccino}

Nutrient content that has been tested in cappuccino are fat and protein content. The sample were tested by the the highest score of overall preferance is cappuccino soy milk with 5\% non dairy creamer. Cappuccino soy milk with $0 \%$ non dairy creamer as the comparison of nutrient value in cappuccino soy milk with $5 \%$ non dairy creamer, and cappuccino using cow's milk as the comparison of nutrient value in cappuccino soy milk with $5 \%$ non dairy creamer. Following Table 5 nutrient content expressed as mean \pm standard deviation in cappuccino using cow's milk, cappuccino soy milk with \% non dairy creamer and cappuccino soy milk with $5 \%$ non dairy creamer.

TABLE V. NUTRITIONAL CONTENT OF CAPUCCINO USING COW'S MILK, CAPUCCINO SOY MILK WITH 0 \% NON DAIRY CREAMER AND CAPUCCINO SOY MILK WITH $5 \%$ NON DAIRY CREAMER

\begin{tabular}{llll}
\hline \multirow{2}{*}{ Parameter } & \multicolumn{2}{c}{ Nutrient content } \\
\cline { 2 - 4 } & \multicolumn{1}{c}{ Cappucino Using Cow's Milk } & \multicolumn{1}{c}{ Cappuccino Soy Milk With 0\% Non Dairy } & \multicolumn{1}{c}{$\begin{array}{c}\text { Cappuccino Soy Milk With 5\% Non } \\
\text { Creamer }\end{array}$} \\
Dairy Creamer
\end{tabular}

In Table 5 can be seen the average of protein content in cappuccino soy milk with $0 \%$ non dairy creamer has the highest protein content among other sample of 0,83505 , while the protein content of cappuccino using cow's milk has the lowest protein content among other cappuccino sample of 0,6489. Protein content in cappuccino soy milk with $5 \%$ non dairy creamer of 0,7146 . Protein in soy milk is a source of vegetable protein in lysine, which is 2300 gr per 100 gr material (Astawan, 2004). Compared to cow's milk the composition of the amino acid in soy milk protein is lowest of amino acids metioninand cystein. But because of lysine amino acid content in soy milk is high enough, so soy milk can increase the nutrional content of protein from rice and other cereal food (Santoso, 2009).

The average of fat content in cappuccino soy milk with $0 \%$ non dairy creamer has the lowest fat content among the other cample with a score 0,458 , while the fat content of cappuccino using cow's milk has the highest score with a score 0,8418 . The fat content in cappuccino soy milk with $5 \%$ non dairy 
creamer is 0,527 . Soy beans have a low fat content but have high content unsaturated fat acid. Unsaturated fat acid are fat acid that don't have a double bond. Unsaturated fat acid are commonly found in vegetable fat. Therefor, soy is well taken by people who are dieting, toddlers and elderly (Muchtadi, 2008). Unsaturated fat content in soybean seeds is $80 \%$, consisting of $21.1 \%$ oleic acid, linoleic acid $52,4 \%$ and linolenic acid 7.1\% (Wahnon, dkk (1988) dalam Maria (2004).

\section{CONCLUSION}

From the results of these research concluded that making cappuccino using soy milk with the addition of non dairy creamer and agitating with homogenization techniques can produce similar products with cappuccino using cow's milk. Cappuccino using soy milk has a highest protein content compared with cappuccino using cow's milk that can replace protein from animal's protein, while the cappuccino using soy milk has a lowest fat content compared with cappuccino using cow's milk that is safe to eat for people who are dieting and people with lactose intolerance.

\section{REFERENCE}

Anonim. (2012). Non dairy creamer https://en.wikipedia.org/wiki/Non-dairy_creamer. Accesed on 10 Mei 2015. Jakarta.

Anonim. (2015). Make The perfect Cup Of Cofee Using A Coffee Machine. http://www.which.co.uk/home-and- garden/small-appliances/guides/make-the-perfect-cup-ofcoffee/using-a-coffee-machine--step-by-step/. Accesed on 18 April 2015. Jakarta

Astawan, M. (2004). Tetap Sehat dengan Produk Makanan Olahan. Tiga Serangkai. Solo

Cahyadi, W. (2004). Kedelai alternatif pemasok protein. ITB, Bandung.

Hadiwiyoto S. (1999). Pembuatan Susu Kedelai. Fakultas Teknologi Pertanian UGM, Yogyakarta.

Koswara, S. (1992). Teknologi Pengolahan Kedelai. Sinar Harapan. Jakarta

Koswara, S. (2009). Teknologi Pengolahan Kedelai Teori dan Praktek. www.e-book.com. Accesed on 19 April 2015

Maria, F. (2004). Pembuatan Susu Bubuk Kedelai Hitam. Skripsi Fakultas

Teknologi Pertanian UGM. Yogyakarta.

Muchtaridi. (2008). Pembuatan Susu Kedelai. Disampaikan pada Penyuluhan di Desa

Jaga Mukti Kecamatan Surade, Sukabumi. Jawa Barat.

Saleh. (2011). Teknologi Pengolahan Susu dan Ikutan Ternak. USU, Sumatera Utara.

Santos. (2008). Kopi dan Teh. Jakarta

Santoso. (2009). Susu dan Yoghurt Kedelai. Kanisius. Yogyakarta

Sudarmadji. (2003). Analisa Bahan Makanan dan Pertanian. Liberty. Yogyakarta 